\title{
TILLING for allergen reduction and improvement of quality traits in peanut (Arachis hypogaea L.)
}

\author{
Joseph E Knoll1,2, M Laura Ramos', Yajuan Zeng ${ }^{1}$, C Corley Holbrook ${ }^{2}$, Marjorie Chow ${ }^{3}$, Sixue Chen ${ }^{3}$, \\ Soheila Maleki ${ }^{4}$, Anjanabha Bhattacharya $^{1}$ and Peggy Ozias-Akins ${ }^{1 *}$
}

\begin{abstract}
Background: Allergic reactions to peanuts (Arachis hypogaea L.) can cause severe symptoms and in some cases can be fatal, but avoidance is difficult due to the prevalence of peanut-derived products in processed foods. One strategy of reducing the allergenicity of peanuts is to alter or eliminate the allergenic proteins through mutagenesis. Other seed quality traits could be improved by altering biosynthetic enzyme activities. Targeting Induced Local Lesions in Genomes (TILLING), a reverse-genetics approach, was used to identify mutations affecting seed traits in peanut.
\end{abstract}

Results: Two similar copies of a major allergen gene, Ara $h$ 1, have been identified in tetraploid peanut, one in each subgenome. The same situation has been shown for major allergen Ara $h$ 2. Due to the challenge of discriminating between homeologous genes in allotetraploid peanut, nested PCR was employed, in which both gene copies were amplified using unlabeled primers. This was followed by a second PCR using gene-specific labeled primers, heteroduplex formation, CEL1 nuclease digestion, and electrophoretic detection of labeled fragments. Using ethyl methanesulfonate (EMS) as a mutagen, a mutation frequency of $1 \mathrm{SNP} / 967 \mathrm{~kb}\left(3,420 \mathrm{M}_{2}\right.$ individuals screened) was observed. The most significant mutations identified were a disrupted start codon in Ara h 2.02 and a premature stop codon in Ara h 1.02. Homozygous individuals were recovered in succeeding generations for each of these mutations, and elimination of Ara h 2.02 protein was confirmed. Several Ara h 1 protein isoforms were eliminated or reduced according to 2D gel analyses. TILLING also was used to identify mutations in fatty acid desaturase AhFAD2 (also present in two copies), a gene which controls the ratio of oleic to linoleic acid in the seed. A frameshift mutation was identified, resulting in truncation and inactivation of AhFAD2B protein. A mutation in AhFAD2A was predicted to restore function to the normally inactive enzyme.

Conclusions: This work represents the first steps toward the goal of creating a peanut cultivar with reduced allergenicity. TILLING in peanut can be extended to virtually any gene, and could be used to modify other traits such as nutritional properties of the seed, as shown in this study.

\section{Background}

Peanut (Arachis hypogaea L.) is an important source of oil and protein, and because of their nutritional benefits and versatility, peanuts and peanut-derived products are used extensively in processed foods. Unfortunately, reports of allergic reactions to peanuts are becoming increasingly common, and severe allergic reactions to peanuts can be fatal [1]. Avoidance is the best strategy to prevent allergic reactions, but due to the prevalence

\footnotetext{
* Correspondence: pozias@uga.edu

'Department of Horticulture/NESPAL, University of Georgia-Tifton Campus, Tifton, GA 31793, USA

Full list of author information is available at the end of the article
}

of peanuts in food products, avoidance can be difficult. Even food which does not specifically contain peanut products, but was processed on equipment also used for handling peanuts, can still contain significant amounts of allergens to trigger allergic response in some patients. Peanuts contain at least 11 potentially allergenic proteins, according to the International Union of Immunological Societies (IUIS) [2]. Knocking out the genes responsible for production of allergenic proteins would be one strategy for reducing the allergic potential of peanuts. However, many of these allergens are seed storage proteins which make up a considerable amount of the total seed protein. Major allergen Ara h 1, for
C Biomed Central

() 2011 Knoll et al; licensee BioMed Central Ltd. This is an Open Access article distributed under the terms of the Creative Commons Attribution License (http://creativecommons.org/licenses/by/2.0), which permits unrestricted use, distribution, and reproduction in any medium, provided the original work is properly cited. 
example, makes up $12-16 \%$ of total seed protein, and Ara h 2 from 5.9-9.3\% [3]. It is unknown how many of these proteins can be eliminated without sacrificing quality or viability, although $\mathrm{Chu}$ et al. [4] used transgenic silencing to eliminate Ara h 2 and Ara h 6 protein in peanut seeds, and observed no adverse effects on viability. Though such results are promising, there are many regulatory obstacles which must be overcome for a transgenic peanut to be used as food.

Another strategy is to use mutagenesis to knock out the allergen genes, or possibly to alter the sequences of major allergenic epitopes in those proteins. This can be accomplished though TILLING (Targeting Induced Local Lesions in Genomes), a technique in which a mutagenized population can be screened for individuals carrying mutations in any known gene of interest. TILLING is a PCR-based technique which relies on mismatch cleavage by CEL1 nuclease to identify singlenucleotide or small insertion/deletion mutations. TILLING was initially developed as a reverse-genetics tool in the model species Arabidopsis thaliana [5], but has since been applied to important crop species including rice (Oryza sativa L.) [6], maize (Zea mays L.) [7], and soybean (Glycine $\max$ (L.) Merr.) [8], to name just a few.

In a previous study we reported the genomic characterization of the major allergen gene Ara $h$ 2[9]. Genes encoding the two isoforms, Ara h 2.01 and Ara h 2.02, are homeologous genes representing orthologs from diploid ancestors, most likely $A$. duranensis (A genome) and $A$. ipaensis (B genome). In this study we show that the major allergen Ara $h 1$ gene is also present in two copies, each belonging to separate subgenomes. Gene-specific primers were developed to identify mutations in each of the two Ara $h 1$ and two Ara $h 2$ genes through TILLING.

In addition to allergen reduction, seed oil composition is another quality trait in peanut that could be targeted using the TILLING approach. Monounsaturated fatty acids are less prone to oxidation than polyunsaturated fatty acids, and thus contribute to better flavor and longer storage life of peanut oil [10]. In addition, monounsaturated fatty acids are nutritionally desirable, and are believed to contribute to cardiovascular health. Linoleic acid (18:2) is a polyunsaturated fatty acid which typically makes up around $15-43 \%$ of peanut oil [11]. In developing seeds it is produced from the monounsaturated oleic acid $(18: 1)$ by the action of $\Delta^{12}$ fatty acid desaturase (AhFAD2). Two homeologous AhFAD2 genes have been identified in peanut, one originating from each subgenome, designated $A h F A D 2 A$ and $A h F A D 2 B[12]$. Reduction in the activity of AhFAD2 increases the ratio of oleic to linoleic acid, but only one functioning allele is required to confer a normal oleate phenotype [13]. Mutations in each of the AhFAD2 genes were also identified using TILLING.

\section{Results}

Determination of Gene Copy Numbers, and Gene-Specific Amplification

Prior to TILLING in a polyploid such as peanut it is necessary to determine the copy number and perform the molecular characterization of any gene of interest, because most genes exist in multiple copies. Co-amplification of multiple homologous sequences would likely result in an excessive number of fragments on TILLING gels, and difficulty in identification of mutations. Also when a mutation is identified, it is necessary to know which gene copy has been altered. In peanut, which is an allotetraploid, genes encoding the two isoforms of Ara h 2 are homeologous, representing orthologs from diploid ancestors [9]. The open reading frames of these two genes are highly similar, with the major difference being an in-frame insertion of 36 bp in Ara $h$ 2.02, resulting in an insertion of 12 amino acids containing an extra copy of the sequence DPYSPS, a known allergenic IgE-binding epitope [14,15]. Gene-specific primer pairs yielded amplicons of $1,280 \mathrm{bp}$ for Ara h 2.01 and 1,227 bp for Ara h 2.02 (Table 1). Each primer pair amplified only one band of expected size from the A- or B-subgenome, and also from the putative progenitors $A$. duranensis and A. ipaensis, respectively [16]. Furthermore, the specific amplification was confirmed by sequence analysis (data not shown).

Prior to designing PCR primers for Ara $h$ 1, two genomic clones of Ara $h 1$ were found in GenBank. The first accession [GenBank: AF432231] was reported by Viquez et al. [17] and is identical to the cDNA sequence of accession L34402 whose encoded protein is designated Ara h 1.0101 by IUIS [2] (isoform Ara h 1.01). A second genomic clone [GenBank: AY581852] was reported by Li et al. [18] and is nearly identical to accession L38853

\section{Table 1 Summary of amplicon sizes and frequencies of mutations identified by TILLING in two different EMS treatments}

\begin{tabular}{|c|c|c|c|c|c|}
\hline \multirow[b]{2}{*}{ Gene } & Amplicon & Screened & $\begin{array}{c}0.4 \% \text { EMS/ } \\
12 \mathrm{hr} .\end{array}$ & $\begin{array}{c}1.2 \% \text { EMS/ } \\
4.5 \mathrm{hr} .\end{array}$ & Total \\
\hline & \multicolumn{2}{|c|}{ bp } & \multicolumn{3}{|c|}{ No. of Mutations: } \\
\hline Ara h 1.01 & 2211 & 2011 & 2 & 2 & 4 \\
\hline Ara h 1.02 & 1666 & 1466 & 1 & 0 & 1 \\
\hline Ara h 2.01 & 1278 & 1078 & 7 & 2 & 9 \\
\hline Ara h 2.02 & 1226 & 1026 & 2 & 3 & 5 \\
\hline Ah FAD2A & 1228 & 1028 & 5 & 0 & 5 \\
\hline$A h F A D 2 B$ & 1221 & 1021 & 3 & 0 & 3 \\
\hline \multirow[t]{3}{*}{ Total: } & 8830 & 7630 & 20 & 7 & 27 \\
\hline & & $\begin{array}{r}\text { Plants } \\
\text { Screened: }\end{array}$ & 2441 & 979 & 3420 \\
\hline & & kb/SNP: & 931 & 1067 & 966 \\
\hline
\end{tabular}

For number of bp screened, $200 \mathrm{bp}$ is subtracted to adjust for the 100-bp regions at the top and bottom of TILLING gel images that are difficult to analyze. 
whose protein is referred to by Chassaigne et al. [19] as isoform 2. For clarity we will refer to this isoform as Ara h 1.02 even though this is not an official IUIS designation. PCR amplification using primers 1306 and 1307 (Table 2) produced two PCR products appearing as a doublet on agarose gel (2,241 bp for Ara $h$ 1.01, and 2,031 bp for Ara $h$ 1.02; Figure 1). Amplicons from gene-specific PCR were 2,211 bp for Ara $h 1.01$ and 1,666 bp for Ara $h 1.02$ (Figure 1; Table 1). Analysis of Ara $h 1$ PCR products from A. hypogaea and its diploid progenitors showed the presence of both genes in $A$. hypogaea, but only one copy in each diploid. The primer pair specific to Ara $h 1.01$ (1306/1308; Table 2) amplified only in A. hypogaea and A. ipaensis (B genome), while the primer pair specific to Ara $h 1.02$ (1306/1309; Table 2) amplified only in A. hypogaea and A. duranensis (A genome; Figure 1). Using the known sequence information, Southern blot analysis of genomic DNA from A. hypogaea was carried out to confirm that no additional copies of Ara $h 1$ are present in the peanut genome. Genomic DNA digested with HindIII, which has no cut sites within either gene, yielded two nearly overlapping fragments of approximately $6.5 \mathrm{~kb}$ each when probed with a full-length Ara $h 1.01$ probe (PCR product of primers 1306/1308). DNA was also digested with EcoRI, which has one cut site in each copy of Ara $h$ 1. Southern blot analysis revealed four fragments, two from each homeolog, as expected. Lastly, the DNA was cut with AseI, which cuts Ara $h 1.01$ (two adjacent cut sites within the second intron), but not Ara $h$ 1.02. As expected, three fragments were produced (Figure 2). EcoRI-digested plasmids carrying either Ara $h 1.01$ or Ara h 1.02 were also loaded as controls; the probe recognized both copies of the gene (data not shown).

Table 2 PCR primers used in this study.

\begin{tabular}{|c|c|c|}
\hline Primer no. & Description & Sequence $\left(5^{\prime}-3^{\prime}\right)$ \\
\hline 813 & $5^{\prime} \operatorname{Arah} 2$ & GGAGTGAAAAAGAGAAGAGAATA \\
\hline 817 & 3' Ara h 2 & TCAAGATGGTTACAACTCTGCAGCAACA \\
\hline 815 & $5^{\prime}$ Ara h 2.01 & CGATTACTCATGTACAATTAACAATAGAT \\
\hline 816 & $5^{\prime}$ Ara h 2.02 & ATCACCTTAAATITATACATATITCGG \\
\hline 371 & 3' Ara h 2 & CAGCAACAAAACATAGACAACGCC \\
\hline 1306 & 5' Arah 1 & GAGCAATGAGAGGGAGGGTT \\
\hline 1307 & 3' Arah 1 & СCTCCTTGGTITTCCTCCTC \\
\hline 1308 & 3' Ara h 1.01 & TTCTCAGGAGACTCTITCTCAGG \\
\hline 1309 & 3' Ara h 1.02 & ССТССТСТTСТТССАСТСТТ \\
\hline 1048 & $3^{\prime}$ AhFAD2 & CTCTGACTATGCATCAG \\
\hline 1055 & $5^{\prime} A h F A D 2 A$ & GATTACTGATTATTGACTT \\
\hline 1101 & $5^{\prime} A h F A D 2 B$ & CAGAACCATTAGCTाTG \\
\hline 1458 & 3' AhFAD2 & CAGAACTTGTTCTTGTACCAATAAACACC \\
\hline 1459 & $5^{\prime} A h F A D 2 B$ & TCAGAACCATTAGCTITGTAGTAGTGC \\
\hline 1460 & $5^{\prime} A h F A D 2 A$ & GATTACTGATTATTGACTTGCTITGTAG \\
\hline
\end{tabular}

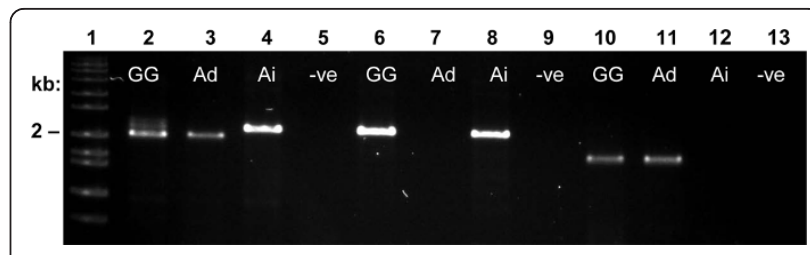

Figure 1 PCR amplification of Ara $h 1$ isoforms on 1\% agarose gel. Lane 1: DNA size standard. Lanes 2-5: primers 1306/1307 amplify both isoforms of Ara $h$ 1. Lanes 6-9: primers 1306/1308 amplify only Ara $h$ 1.01. Lanes 10-13: primers 1306/1309 amplify only Ara h 1.02. $\mathrm{GG}=$ A. hypogaea cv. Georgia Green, $\mathrm{Ad}=A$. duranensis (A genome), $\mathrm{Ai}=\mathrm{A}$. ipaensis ( $\mathrm{B}$ genome), $-\mathrm{ve}=$ negative control.

Another target for TILLING, the $\Delta^{12}$-fatty acid desaturase gene $A h F A D 2$ has been characterized in studies by Jung et al. [12], López et al. [20], and Patel et al. [21]. This gene is also present in two copies, one in each subgenome of $A$. hypogaea. The gene sequences are highly conserved between the two, except for an insertion of

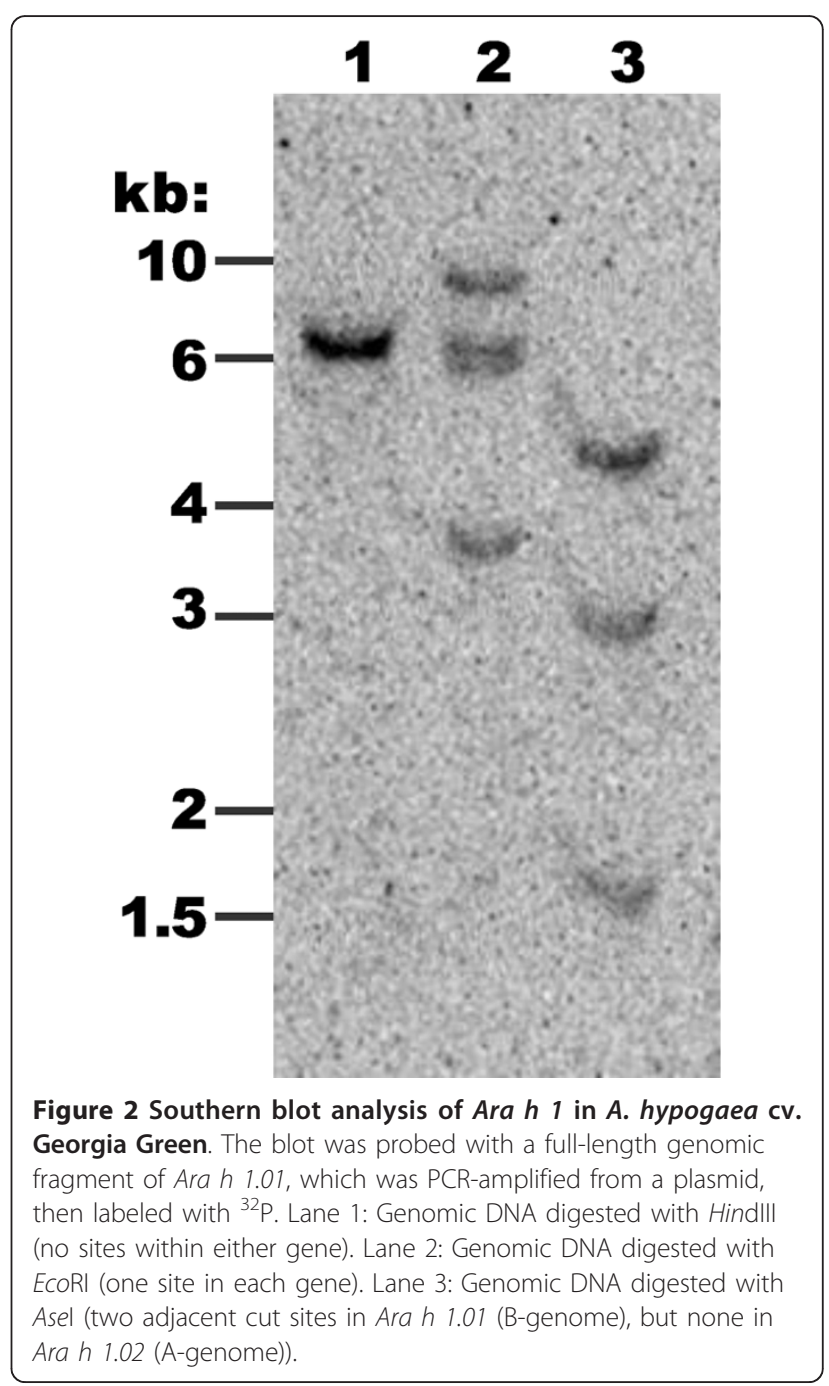


19 bp in $A h F A D 2 A$ (or a deletion in AhFAD2B), $80 \mathrm{bp}$ upstream of the start codon. Gene-specific primer sequences utilizing this indel produce amplicons nearly identical in size: $1,228 \mathrm{bp}$ for $A h F A D 2 A$ and $1,221 \mathrm{bp}$ for $A h F A D 2 B$ (Table 1).

\section{Peanut TILLING Populations and Mutation Frequencies}

Several populations were created using ethyl methanesulfonate (EMS) and one with diethylsulfate (DES). The concentration of mutagen and time of treatment were selected from preliminary experiments that gave 30\%$50 \%$ seed germination. From the DES-treated $\mathrm{M}_{2}$ population, 352 plants were screened for all six genes, and no mutations were detected. Two EMS mutagenesis treatments were tested in this study, $1.2 \%$ for $4.5 \mathrm{~h}$ and $0.4 \%$ for $12 \mathrm{~h}$. A total of 3,420 EMS-treated $\mathrm{M}_{2}$ plants were screened, each for all six genes $(7,630 \mathrm{bp} /$ plant; Table 1). Twenty-seven SNPs were detected and confirmed. The overall mutation frequency for EMS was 1 SNP/967 $\mathrm{kb}$. For $1.2 \%$ EMS at $4.5 \mathrm{~h}$, the mutation rate was 1 $\mathrm{SNP} / 1,067 \mathrm{~kb}$ (979 plants). The mutation frequency for $0.4 \%$ EMS for $12 \mathrm{~h}$ was slightly higher at $1 \mathrm{SNP} / 931 \mathrm{~kb}$ $(2,441$ plants), although this difference probably is not significant. Most of the nucleotide changes were $\mathrm{G}$ to $\mathrm{A}$ or $\mathrm{C}$ to $\mathrm{T}$, as expected for EMS-induced transitions. Several unusual mutations were found in $A h F A D 2 A$ and $A h F A D 2 B$, which may not be the result of the EMS treatment (Table 3). If that is the case, then the average mutation frequency would be $1 \mathrm{SNP} / 1186 \mathrm{~kb}$.

\section{Ara $h 2$ Mutations}

In total, nine SNPs were identified in Ara $h$ 2.01, and five in Ara $h$ 2.02. The first two amino-acid changes identified were in Ara $h$ 2.01 in lines 20-6 (L 49 F) and 37-4 (R $55 \mathrm{H}$; Table 3). Line 37-4 actually had two nucleotide changes in this gene, but one of them was silent. These two mutations were confirmed in the $M_{3}$ and $\mathrm{M}_{4}$ generations using TILLING. DNA from $\mathrm{M}_{3}$ or $\mathrm{M}_{4}$ individuals was analyzed both alone and mixed with wild type DNA. Homozygotes were identified when SNPs were detected in mixed samples but not in the corresponding unmixed samples. Homozygous mutants allowed the testing of IgE binding on the altered proteins from seed extracts. Total protein extracts from homozygous $\mathrm{M}_{4}$ lines of 20-6 and 37-4 were normalized for loading equal amounts of Ara h 2.01, as measured by anti-Ara $\mathrm{h} 2$ chicken polyclonal antibody, and were tested for binding to serum from four patients with peanut hypersensitivity (HW, DAM, CM, and NF). The IgE-immunoblot showed no differences between the native Ara h 2.01 present in the peanut cultivar Georgia Green (GG) [22] and the Ara h 2.01 allelic variants detected by TILLING in lines 20-6 and 37-4 (Figure 3). Although the mutations were generated in cultivar
Table 3 Mutations identified by TILLING in this study

\begin{tabular}{|c|c|c|c|c|}
\hline \multicolumn{5}{|c|}{ Treatment:0.4\% EMS for $12 \mathrm{hr}$. } \\
\hline Gene & $\begin{array}{l}\text { Nucleotide } \\
\text { Change }\end{array}$ & $\begin{array}{l}\text { Predicted AA } \\
\text { Change }\end{array}$ & Population & $\begin{array}{l}\text { Plant } \\
\text { ID }\end{array}$ \\
\hline Ara h 2.01 & $\mathrm{C} 145 \rightarrow \mathrm{T}$ & $\mathrm{L} 49 \rightarrow \mathrm{F}$ & 05 & $20-6$ \\
\hline Ara h 2.01 & $\mathrm{G} 164 \rightarrow \mathrm{A}$ & $\mathrm{R} 55 \rightarrow \mathrm{H}$ & 05 & $37-4$ \\
\hline $\operatorname{Ara} h 2.01$ & $\mathrm{G} 192 \rightarrow \mathrm{A}$ & silent & 05 & $37-4$ \\
\hline Ara h 2.01 & $\mathrm{G} 186 \rightarrow \mathrm{A}$ & silent & 07G & $78-4$ \\
\hline Ara h 2.01 & $\mathrm{C} 80 \rightarrow \mathrm{T}$ & silent & $07 \mathrm{G}$ & $90-4$ \\
\hline Ara h 2.01 & $\mathrm{G} 357 \rightarrow \mathrm{A}$ & silent & 07JKEMS1 & 65 \\
\hline Ara h 2.01 & $\mathrm{G} 186 \rightarrow \mathrm{A}$ & silent & 08GH & 250 \\
\hline Ara h 2.02 & $\mathrm{G} 185 \rightarrow \mathrm{A}$ & $\mathrm{R} 62 \rightarrow \mathrm{Q}$ & 07G & $89-5$ \\
\hline Ara h 2.02 & $\mathrm{G} 3 \rightarrow \mathrm{A}$ & $\begin{array}{l}\text { disrupted start } \\
\text { codon }\end{array}$ & 08GH & 2 \\
\hline Ara h 1.01 & $\mathrm{C} 1392 \rightarrow \mathrm{T}$ & $\mathrm{R} 333 \rightarrow \mathrm{W}$ & 07G & $95-1$ \\
\hline Ara h 1.01 & $\mathrm{C} 586 \rightarrow \mathrm{T}$ & silent & 07JKEMS1 & 99 \\
\hline Ara h 1.02 & $\mathrm{C} 304 \rightarrow \mathrm{T}$ & R102 $\rightarrow$ Stop & 07JKEMS1 & 133 \\
\hline AhFAD2A & $\mathrm{A} 448 \rightarrow \mathrm{G}$ & $\mathrm{N} 150 \rightarrow \mathrm{D}$ & 05 & $4-3$ \\
\hline AhFAD2A & $\mathrm{A} 448 \rightarrow \mathrm{G}$ & $\mathrm{N} 150 \rightarrow \mathrm{D}$ & 05 & $55-4$ \\
\hline AhFAD2A & $\mathrm{A} 448 \rightarrow \mathrm{G}$ & $\mathrm{N} 150 \rightarrow \mathrm{D}$ & 05 & $\begin{array}{l}138- \\
10\end{array}$ \\
\hline AhFAD2A & $\mathrm{C} 718 \rightarrow \mathrm{T}$ & silent & $07 G$ & $113-5$ \\
\hline AhFAD2A & $\mathrm{C} 761 \rightarrow \mathrm{T}$ & $\mathrm{P} 254 \rightarrow \mathrm{L}$ & 07JKEMS1 & 72 \\
\hline AhFAD2B & A442 insertion & frameshift & 05 & $69-8$ \\
\hline$A h F A D 2 B$ & A442 insertion & frameshift & $07 G$ & $81-4$ \\
\hline AhFAD2B & $\mathrm{C} 566 \rightarrow \mathrm{T}$ & silent & 07JKEMS1 & 2 \\
\hline \multicolumn{5}{|c|}{ Treatment:1.2\% EMS for $4.5 \mathrm{hr}$. } \\
\hline Gene & $\begin{array}{l}\text { Nucleotide } \\
\text { Change }\end{array}$ & $\begin{array}{l}\text { Predicted AA } \\
\text { Change }\end{array}$ & Population & $\begin{array}{l}\text { Plant } \\
\text { ID }\end{array}$ \\
\hline Ara h 2.01 & $\mathrm{G} 243 \rightarrow \mathrm{A}$ & $\mathrm{A} 82 \rightarrow \mathrm{T}$ & O6EF & $13-6$ \\
\hline Ara h 2.01 & $\mathrm{G} 192 \rightarrow \mathrm{A}$ & silent & 06LREMS1 & $8-4$ \\
\hline Ara h 2.02 & $\mathrm{G} 208 \rightarrow \mathrm{A}$ & $\mathrm{D} 70 \rightarrow \mathrm{N}$ & O6EF & $23-7$ \\
\hline Ara h 2.02 & $\mathrm{G} 208 \rightarrow \mathrm{A}$ & $\mathrm{D} 70 \rightarrow \mathrm{N}$ & O6EF & $26-1$ \\
\hline Ara h 2.02 & $\mathrm{G}-315 \rightarrow \mathrm{A}$ & $\begin{array}{l}\text { upstream, } \\
\text { probably silent }\end{array}$ & O6EF & $62-6$ \\
\hline Ara h 1.01 & $\mathrm{C} 1609 \rightarrow \mathrm{T}$ & P405 $\rightarrow$ L & O6EF & $53-3$ \\
\hline Ara h 1.01 & $\mathrm{G} 1704 \rightarrow \mathrm{A}$ & $\mathrm{E} 437 \rightarrow \mathrm{K}$ & 06EF & $56-3$ \\
\hline
\end{tabular}

Tifrunner [23] there is no difference between the Ara $h$ 2.01 proteins of these two cultivars.

Four more silent mutations were found in Ara h 2.01, one of which is identical to the silent mutation in line 37-4. One other amino acid change (A $82 \mathrm{~T}$ ) was also identified in Ara $h$ 2.01. Three amino acid changes were identified in Ara $h$ 2.02, but two of them (D $70 \mathrm{~N}$ ) are identical (Table 3). This change occurs in the second DPYSPS motif, which is a known allergenic epitope $[14,15]$. The third amino acid change ( $\mathrm{R} 62 \mathrm{Q})$ also lies within an allergenic epitope, just before the first DPYSPS motif (Additional File 1). Because homozygous seed has not yet been recovered, the ability of these mutant proteins to bind IgE has not yet been tested, although these look to be promising candidates for reduced allergenicity of Ara h 2.02. A G to A mutation 


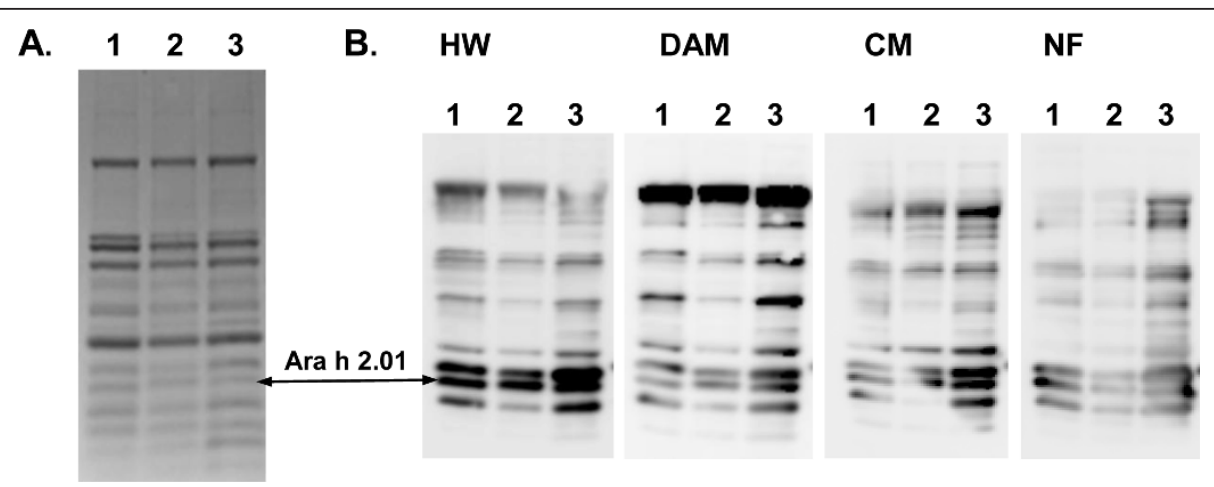

Figure $3 \mathrm{lgE}$ binding analysis of seed protein extracts from $M_{4}$ generation of Ara h 2.01 mutant lines 20-6 and 37-4. A - Equal amount of total protein from seeds of wild type (Georgia Green; Lane 1), mutant line 37-4 (Lane 2), and mutant line 20-6 (Lane 3) loaded on SDS-PAGE stained with Coomassie blue. B - IgE inmunoblot performed with serum from patients with peanut hypersensitivity (HW, DAM, CM, and NF). Lane numbers are the same as in panel $4 \mathrm{~A}$.

was also found 315 bp upstream of the start codon of Ara $h$ 2.02; however, it does not appear to be located within any important promoter elements.

Lastly, a G to A transition was identified in the start codon of Ara $h$ 2.02. A downstream ATG is out of frame, and so a protein knockout was expected. Two $\mathrm{M}_{3}$ seeds were recovered, a small chip was taken from each for protein analysis, and the seeds were planted. Both seeds grew into phenotypically normal plants. SDS-PAGE analysis of the seed protein extracts confirmed that one of the seeds was indeed missing the 21 $\mathrm{kD}$ band which represents the Ara h 2.02 protein [9], and was thus homozygous for the mutation (Figure 4A). The other seed appeared to have a reduced quantity of Ara h 2.02; DNA sequence analysis (data not shown) confirmed that this plant was a heterozygote. Western blot analysis (Figure 4B) also confirmed the absence of Ara h 2.02 protein in the homozygous mutant. Further analysis with 2-D difference gel electrophoresis (2-D DIGE) confirmed that both of the Ara h 2.02 isoforms, shown to differ by a two amino acid truncation at the carboxy terminus [24], were missing in the homozygous mutant line (Figure 4C).

\section{Ara $h 1$ Mutations}

In the longest amplicon, Ara $h 1.01$ (2,211 bp), signals from both IRDye channels sometimes were not visible on Li-Cor gels due to background and fragment length, but SNPs identified from single-channel signals were later verified by sequencing. Four mutations have been confirmed in Ara h 1.01 (Table 1). One of these, a C to $\mathrm{T}$ transition at bp position 593, is silent, but the other three are predicted to induce amino acid changes: $\mathrm{R} 333$ W, P $405 \mathrm{~L}$, and E $437 \mathrm{~K}$ (Table 3; Additional File 2). The arginine to tryptophan change at position 333 lies within epitope 12 [25]. Only one mutation was confirmed in Ara $h$ 1.02; a premature stop codon is produced at bp position 304 by a $\mathrm{C}$ to $\mathrm{T}$ mutation. This is expected to result in a truncated protein of 102 amino acids (Line 133; Additional File 2). All four of these non-silent mutations have been confirmed in the $\mathrm{M}_{3}$ generation by TILLING. A CAPS (cleaved amplified polymorphic sequence) marker was developed to detect the Ara $h 1.02$ truncation mutant in succeeding generations. The wild-type amplicon contains six BslI sites, one of which is deleted in the mutant. This marker was used to identify a homozygous mutant in the $\mathrm{M}_{4}$ generation (Figure 5).

Both Ara h 1 proteins appear as a thick band of approximately $63.5 \mathrm{kD}$ on SDS-PAGE [26]. Although the two genes encode proteins of slightly different sizes, we were unable to resolve both of them with onedimensional electrophoresis. Thus, 2D SDS-PAGE and 2D-DIGE were attempted to confirm the absence of the protein in seeds of the homozygous Ara $h 1.02$ truncation mutant. From the 2-D PAGE and 2-D Western blot (Additional File 3) it was not possible to resolve only two distinct Ara h 1 isoforms, an expected result based on published 2-D gel analyses for Ara h 1 [19]. Multiple post-translational protein modifications (i.e. various cleavage products or glycosylation) are produced from the two isoforms of Ara h 1. However, there was a definite difference in the relative Cy3 (wild-type) and Cy5 (mutant) signal intensities for the group of spots in the $\mathrm{pI}$ range of 5.9-6.4 representing Ara $\mathrm{h}$ 1. From these data it is not possible to conclude that the Ara $h 1.02$ isoform has been completely eliminated. However, quantitative analysis of the 2-D DIGE mutant and wild-type gels showed that the intensities of three pI 5.9-6.0 spots representing Ara h 1 (Figure 6A, spots 474, 482, 485) were reduced 2.4-2.6-fold in the mutant, but others with a higher pI appeared to increase (1.5-3.5-foldTable 4), although these isoforms were less abundant than the lower $\mathrm{pI}$ isoforms in both wild-type and mutant. Also, 


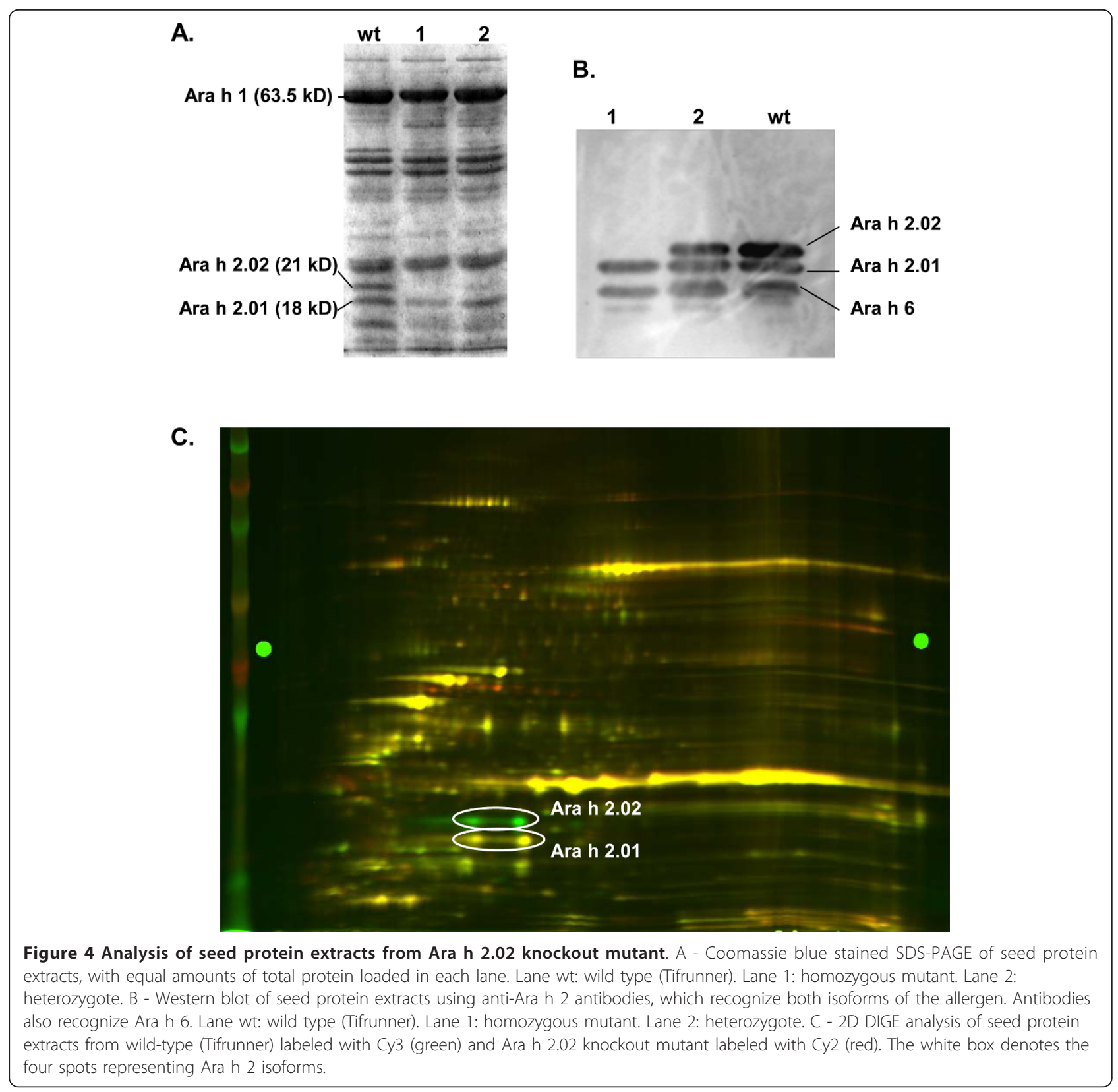

spots 482 and 485/491 which appear as doublets in the wild-type (Figure 6B) appear as single spots in the mutant (Figure 6C), suggesting that several protein products have indeed been eliminated in the mutant.

\section{AhFAD2 Mutations}

One silent mutation was found in each of $A h F A D 2 A$ and $A h F A D 2 B$, and one predicted amino acid change (P 254 L) was found in $A h F A D 2 A$. All three of these mutations were $\mathrm{C}$ to $\mathrm{T}$ transitions, typical for EMS-induced mutations. Several mutations were also identified in these genes which were not typical: an A-insertion, observed twice in $A h F A D 2 B$, and three identical A to $\mathrm{G}$ mutations in $A h F A D 2 A$ (Table 3). These are unusual for EMSinduced mutations, but it is perhaps the location and frequency of these mutations which is most intriguing. The A-insertion in $A h F A D 2 B$ occurs 442 bp after the start codon, causing a frameshift, and likely resulting in a truncated protein due to a premature stop codon (line 81-4; Additional File 4). This mutation was identified in two different $\mathrm{M}_{2}$ plants in our TILLING populations. Using a CAPS marker [27], this mutation has been shown to be stably inherited in the $M_{3}$ generation derived from one of our TILLING mutants (data not shown). In $A h F A D 2 A$, three different $\mathrm{M}_{2}$ plants were found to contain the same mutation, an $\mathrm{A}$ to $\mathrm{G}$ transition at $448 \mathrm{bp}$ 


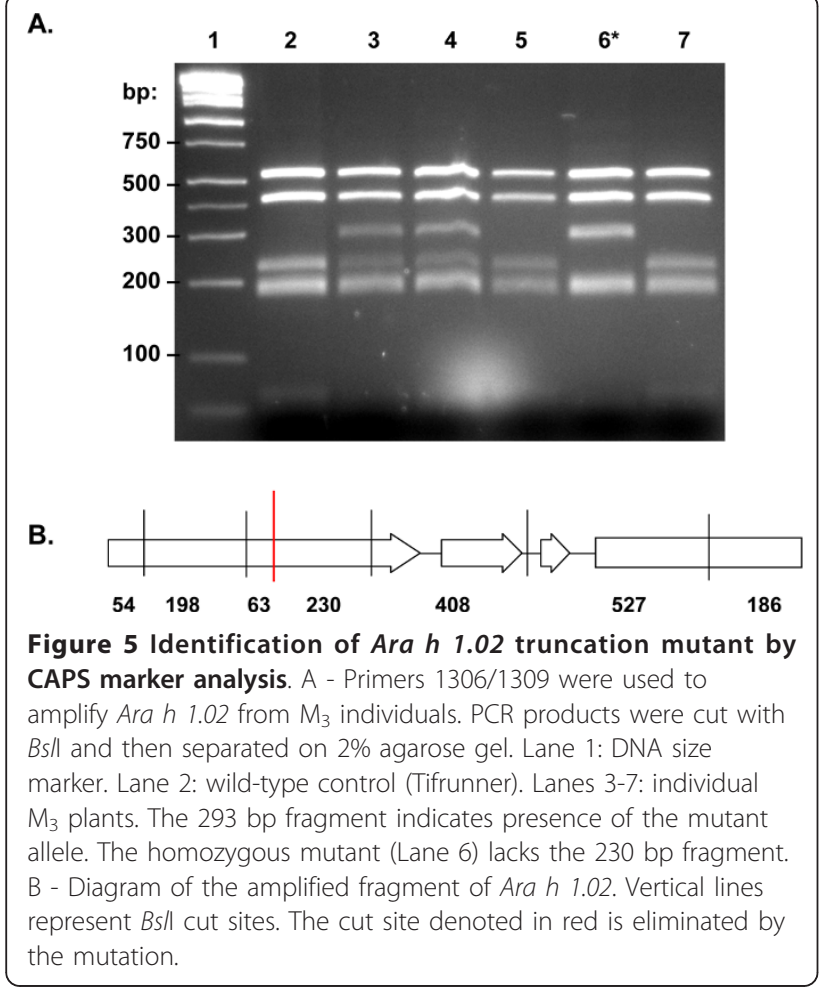

after the start codon. This is predicted to change the amino acid at position 150 from asparagine to aspartic acid (line 4-3; Additional File 4).

\section{Discussion}

In TILLING populations of diploids such as sorghum (Sorghum bicolor (L.) Moench) [28] and Lotus japonicus [29], phenotypic mutants were frequently observed. In contrast, very few phenotypic mutations were observed in field or greenhouse-grown $\mathrm{M}_{2}$ peanut plants in this study, most likely due to genetic buffering caused by polyploidy, similar to that observed in TILLING populations of tetraploid and hexaploid wheat (Triticum aestivum L.) [30]. In EMS-mutagenized hexaploid wheat, a mutation frequency of $1 \mathrm{SNP} / 24 \mathrm{~kb}$ has been reported, and $1 \mathrm{SNP} / 40 \mathrm{~kb}$ was reported in tetraploid wheat [30]. The mutation rate observed in this study on peanut is much lower than that reported for wheat and lower than Arabidopsis (1 SNP/ 300 kb [4]), or most legumes including soybean (1 SNP/140-550 kb depending on treatment [8]), and pea (Pisum sativum L.; 1 SNP/669 $\mathrm{kb}$ [31]; $1 \mathrm{SNP} / 200 \mathrm{~kb}$ [32]). It is similar to or higher than that in some populations of barley (Hordeum vulgare L.; $1 \mathrm{SNP} / 2500 \mathrm{~kb}$ [33], $1 \mathrm{SNP} / 1000 \mathrm{~kb}$ [34]) and

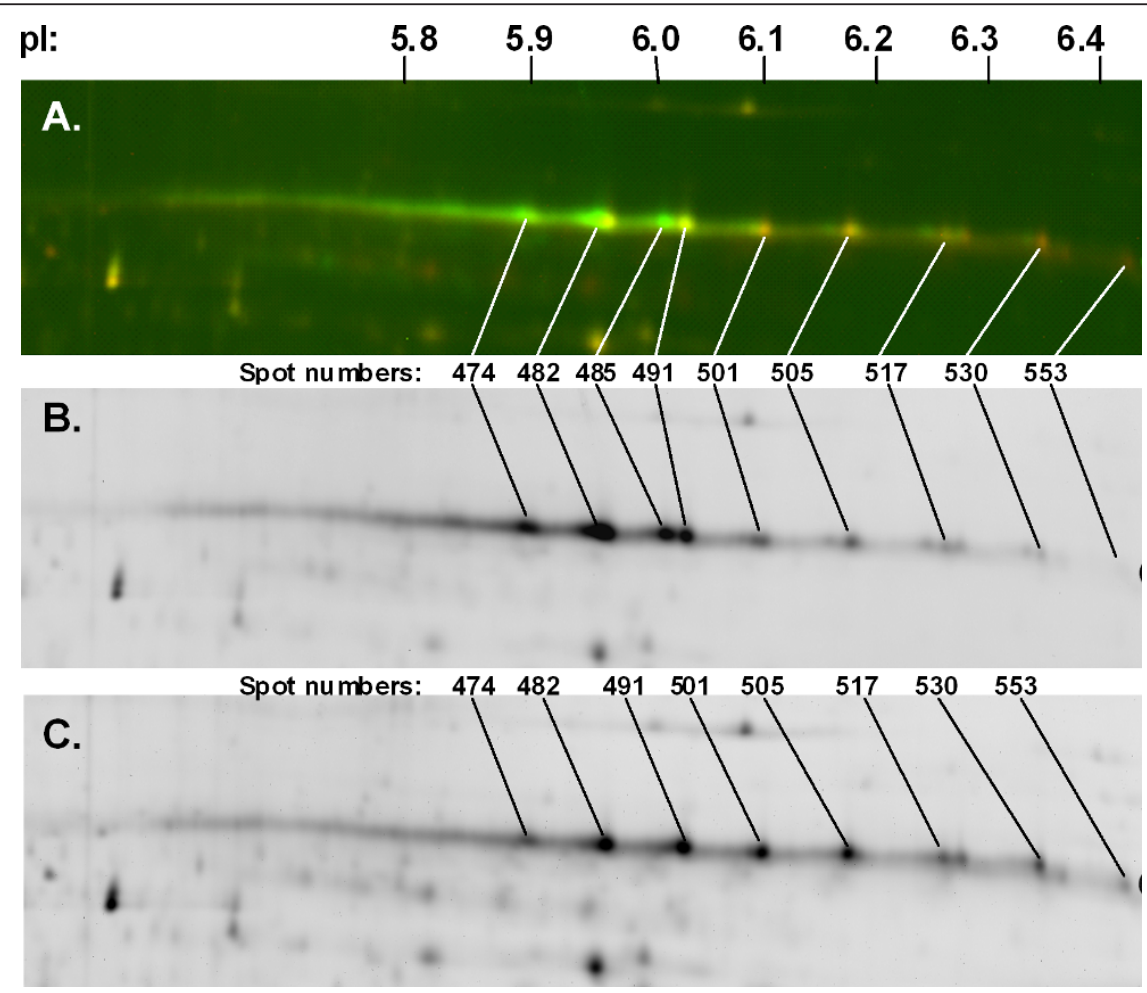

Figure 6 2D DIGE analysis of Ara h 1.02 truncation mutant. Protein extracted from seeds of homozygous wild-type (Tifrunner) was labeled with Cy3 (green), and seed protein from Ara h 1.02 truncation mutant was labeled with Cy5 (red). Labeled proteins were separated by 2-D DIGE with a pl range of 5.3-6.5. Region of 2-D gel where most Ara $\mathrm{h} 1$ protein separates is shown in detail. A - Two-color image. Wild-type protein is green; mutant protein is red. B - Single-color image of wild-type protein only. C - Single-color image of mutant protein. 


\begin{tabular}{|c|c|c|c|c|c|}
\hline $\begin{array}{l}\text { Spot } \\
\text { No. }\end{array}$ & $\mathrm{pl}$ & $\begin{array}{c}\text { Mass } \\
(\mathrm{kD})\end{array}$ & $\begin{array}{c}\text { Max } \\
\text { Volume }\end{array}$ & $\begin{array}{c}\text { Volume } \\
\text { Ratio }\end{array}$ & Abundance \\
\hline 474 & 5.90 & 56,559 & $1,596,575$ & -2.57 & Decreased \\
\hline 482 & 5.96 & 56,281 & $2,763,712$ & -2.40 & Decreased \\
\hline 485 & 6.02 & 56,147 & $1,360,494$ & -2.67 & Decreased \\
\hline 491 & 6.04 & 56,052 & $1,480,757$ & -1.27 & Similar \\
\hline 501 & 6.10 & 55,805 & 639,866 & 1.55 & Increased \\
\hline 505 & 6.18 & 55,745 & 827,950 & 1.53 & Increased \\
\hline 517 & 6.28 & 55,488 & 338,574 & 1.51 & Increased \\
\hline 530 & 6.35 & 55,220 & 270,914 & 3.00 & Increased \\
\hline 553 & 6.42 & 54,463 & 131,587 & 3.57 & Increased \\
\hline
\end{tabular}

(Spot numbers correspond to Figure 6.)

rice (1 SNP/1000 kb [35]). As with barley and rice, mutation density potentially could be improved by using alternate genotypes, treatment conditions, or choice of mutagens $[6,36]$. No mutations were detected in the DES-mutagenized population, even though this chemical was used to recover a high oleic acid mutant of peanut [37]. In the present study, an incubation time of $4.5 \mathrm{~h}$ at a concentration of $0.25 \%$ was substantially different from that used by Moore [37] (15 min at 1.5\%). With the longer incubation time of $4.5 \mathrm{~h}$, no germination occurred at a concentration greater than $0.5 \%$.

The IgE-immunoblot showed no differences between the wild-type Ara h 2.01 and the Ara h 2.01 allelic variants detected by TILLING in lines 20-6 and 37-4 (Figure 3), despite the fact that both of these changes affect known IgE epitopes $[14,15]$. Although a reduction in IgE binding was not detected with these two allelic variants, it has been shown that a small change in this protein can indeed have this desired effect. In a recent study Ramos et al. [38] identified a naturally occurring variant (a serine to threonine change at position 73) in an accession of $A$. duranensis that showed 56-99\% reduction in IgE binding compared to wild-type Ara h 2.01. The arginine to tryptophan change at position 333 in Ara h 1.01 lies within epitope 12 [25]. Although it is unlikely that this residue is critical for IgE binding [25], and the other two amino acid changes do not reside within known epitopes, the possibility of reduced IgE affinity cannot be completely ruled out until these proteins are tested.

The Ara h 1.01 and Ara $h 1.02$ genes code for proteins with predicted sizes of 71.3 and $70.3 \mathrm{kD}$, respectively, but the mature proteins extracted from seeds appear as a single $63.5 \mathrm{kD}$ band on SDS-PAGE [26]. The N-terminal amino acid sequence of the purified proteins does not match the predicted $\mathrm{N}$-terminal sequence; rather it is located 78 or 84 amino acids downstream, depending on the isoform $[39,40]$. These first 78 or 84 amino acids, along with an included 25 amino acid signal peptide, are cleaved off during posttranslational processing. The 53 or 59 amino acid cleaved peptides contain six of the seven cysteines found in Ara h 1 isoforms [40] and three of the allergenic epitopes [41], and are hypothesized to form disulfide bridges conferring a stable conformation similar to plant antifungal peptides [40]. In our Ara h 1.02 truncation mutant, the truncation occurs downstream of the cleavage site potentially leaving the cleaved peptide intact. It remains to be seen whether the cleavage product is still produced and stable in seeds of the mutant.

A previously described mutant allele of $A h F A D 2 B$ contains an A-insertion 442 bp after the start codon, causing a frameshift, and likely results in a truncated protein due to a premature stop codon [20]. This mutant allele has been reported previously in multiple independently derived cultivars which have a high oleic to linoleic acid ratio (high $\mathrm{O} / \mathrm{L}$ ), most likely due to the inactivity of AhFAD2B [27]. The same mutation was identified in two different $\mathrm{M}_{2}$ plants in our TILLING populations. It is possible that this mutant allele is present at a low frequency in the source seed for the TILLING population, although these seed were produced before extensive breeding for the high $\mathrm{O} / \mathrm{L}$ trait was initiated in the USDA-ARS program. Furthermore, independent generation of this mutant allele has been reported in China and the U.S. [27]. Even more surprising, three different $M_{2}$ plants were found to contain a reversion to the wild-type allele of $A h F A D 2 A$, an A to G transition at $448 \mathrm{bp}$ after the start codon, whereas the TILLING population parent, 'Tifrunner', possesses the mutant allele. This reversion is predicted to change the amino acid at position 150 from asparagine to aspartic acid and restore functionality to the desaturase enzyme. In most runner-type peanut cultivars, the AhFAD2A protein is presumed to be inactive due to the presence of the asparagine residue at position 150 [42]. The aspartic acid residue is likely an important component of the active site of the enzyme and is highly conserved among fatty acid desaturases from other plants, including A. duranensis, from which AhFAD2A likely is derived [13]. Based on a survey of the mini-core of the U.S. peanut germplasm collection, Chu et al. [42] found that the aspartic acid residue also appears to be conserved among Spanish and Valencia market types of peanut, but the inactive allele was found to be common (75\%) among Virginia and Runner market-types. In our three independent TILLING mutants, the asparagine has been mutated back to aspartic acid, most likely restoring the function of AhFAD2A. In a recombinant AhFAD2A protein with the aspartic acid restored at position 150 by site-directed mutagenesis, Bruner et al. [43] showed that its full function is indeed restored. 
Both the frequency and the nature of these two mutations are atypical of mutations induced by EMS, including the other mutations observed in this study. It is unclear whether these mutations are due to the EMS treatment, outcrossing, or genetic impurity in the starting seed, but the latter appears to be the most likely explanation. If that is the case, then assessment of genetic purity at specific loci may be another use for mismatch-based mutation detection.

\section{Conclusions}

These experiments represent the initial steps toward the development of a hypoallergenic peanut. Because genetic variation for allergens is limited in cultivated peanut, mutagenesis is necessary to generate variation. We have shown that TILLING is a useful technique for screening mutagenized populations of peanut for induced changes in allergen genes. When multiple seed storage proteins with reduced IgE binding are identified, or more knockout mutations are found, the next step will be a concerted breeding effort to combine these mutant alleles into one plant. TILLING, CAPS markers, or a more efficient SNP assay can be used as tools to track the inheritance of these alleles in the breeding process. TILLING in peanut can be extended to virtually any gene, and could be used to assist in the modification of other traits such as disease resistance, stress tolerance, early maturity, or as shown in this study, nutritional properties of the seed.

\section{Methods}

\section{Southern Blot Analysis of Ara $h 1$}

DNA for Southern blot analysis was isolated from young leaves of peanut (Arachis hypogaea L.) cv. Georgia Green [22] using the DEAE-cellulose-based technique of Sharma et al. [44]. Twenty micrograms of purified genomic DNA was digested overnight with AseI, EcoRI, or HindIII, and was then loaded on a $0.7 \%$ agarose gel and electrophoresed in TBE buffer at $45 \mathrm{~V}$ for approximately nine hours. EcoRI-digested pCR-4 TOPO plasmids (Invitrogen, Carlsbad, CA) carrying either Ara $h 1.01$ or Ara h 1.02 (clones derived from PCR products using primer pairs 1306/1308 and 1306/1309, respectively; Table 2) were also loaded in adjacent lanes as positive controls. The DNA was transferred to Genescreen Plus nylon membrane (Perkin-Elmer, Boston, MA) overnight using the alkaline transfer method [45]. The membrane was probed with a full-length genomic fragment of Ara $h$ 1.01, which was PCR-amplified from a plasmid carrying the fragment. The probe was labeled with $\alpha^{32} \mathrm{P}-\mathrm{dCTP}$ using the Random Primed DNA Labelling Kit (Roche, Indianapolis, IN). Unincorporated label was removed using Sephadex G-50 (Sigma, Saint Louis, MO). Hybridization and washing conditions were as described by Sambrook and Russell [45]. The final wash was carried out at $65^{\circ} \mathrm{C}$ for $15 \mathrm{~min}$. in $0.5 \times \mathrm{SSC}$ buffer $(75 \mathrm{mM}$ $\mathrm{NaCl}, 7.5 \mathrm{mM}$ sodium citrate, $\mathrm{pH} 7.0$ ) with $0.1 \%$ SDS. The blot was visualized by exposure to a Storage Phosphor Screen (Amersham Biosciences, Piscataway, NJ) which was then scanned using a Storm 840 imaging system (Amersham Biosciences).

\section{Mutant Peanut Populations}

Ethyl methanesulfonate (EMS) or diethylsulfate (DES) treatments were used to induce mutations in the peanut cultivar 'Tifrunner' [23]. Seeds were imbibed in tap water for 10-12 hours. The tap water was then replaced with aqueous solution of mutagen. Three mutagen treatments were tested: $0.4 \%$ EMS for $12 \mathrm{~h}, 1.2 \%$ EMS for 4.5 $\mathrm{h}$, or $0.25 \%$ DES for $4.5 \mathrm{~h}$. Seeds were soaked in the mutagen solution in $2 \mathrm{~L}$ Fernbach flasks on a rotary shaker, and were then washed three times in deionized water. (Washes were collected for disposal). The seeds were then rinsed in running water overnight. The $M_{1}$ seeds were planted in the field, and one pod was harvested from each plant to generate an $M_{2}$ population. $M_{2}$ seeds were planted in either the field or greenhouse, and $\mathrm{M}_{3}$ seed was harvested from them to create permanent TILLING populations.

The entire population will not be distributed because of limited seed availability, although screening for specific mutant genes and distribution of individual lines is possible.

\section{DNA Isolation and Quantification for TILLING}

Young leaf tissue was collected from individual $M_{2}$ plants, frozen using liquid nitrogen, and either stored at $-80^{\circ} \mathrm{C}$ or lyophilized directly in 96 -well collection plates. It was then ground into powder by vortexing with three to four 3-mm stainless-steel grinding balls in 2-ml flatbottom microcentrifuge tubes, or using a GenoGrinder 2000 (OPS Diagnostics LLC, Bridgeview, NJ), set at 500 strokes/min for $20 \mathrm{sec}$ (liquid nitrogen-frozen tissue), or 1 min (lyophilized tissue). Genomic DNA was extracted using the DNeasy 96 Plant Kit (Qiagen Inc. USA, Valencia, CA) according to the manufacturer's instructions. The DNA was quantified by fluorometry using either PicoGreen (Invitrogen, Carlsbad, CA) or Hoechst 33258 dye in a FluoroCount (Packard/Perkin-Elmer, Waltham, MA) microplate reader. Samples of purified DNA were also run on agarose gel to verify quality. Individual DNA samples were diluted to a working concentration of $5 \mathrm{ng} /$ $\mu l$. Individual DNA samples were then four-fold pooled in 96-well format. For verification of individual mutants, genomic DNA from 'Tifrunner' was used as the control.

\section{Primer Design and PCR}

Since Ara $h 2$ genes are small and without introns, differences in the upstream regions of these two genes 
were used to design gene-specific primers for TILLING (Primers 815 and 816). Based on the available sequence information in GenBank, primers 1306 and 1307 were designed to amplify both copies of Ara $h$ 1. Indels near the 3 ' end of the open reading frame allowed us to design gene-specific primers 1308 (Ara $h$ 1.01) and 1309 (Ara $h$ 1.02). Primer sequences 1055 (AhFAD2A) and 1101 (AhFAD2B) utilize the indel $80 \mathrm{bp}$ upstream of the start codon to amplify one specific gene copy. These primers are identical to primers aF19 and bF19 used by Patel et al. [21]. For amplification with IRDye-labeled primers, longer oligos are preferred, so primers 1458 , 1459 , and 1460 were designed. All primer sequences used in this study are shown in Table 2.

Because peanut DNA is highly complex, a first round of unlabeled PCR was used to increase the concentration of target sequences for subsequent labeled PCR. Based on available sequence information and suitability of priming sites, primers for the first round of PCR were designed to amplify both copies of Ara $h$ 2, both copies of Ara h 1, or one specific copy of AhFAD2. The first PCR was carried out in a $25 \mu \mathrm{l}$ final volume containing 10 ng gDNA, 0.5 U JumpStart Taq DNA Polymerase in $1 \times$ PCR Buffer (Sigma, Saint Louis, MO), 0.2 $\mathrm{mM}$ each dATP, dCTP, dGTP and dTTP, and $0.2 \mu \mathrm{M}$ each forward and reverse primers, under the following conditions: $94^{\circ} \mathrm{C}$ for $1 \mathrm{~min}$; followed by 8 cycles at $94^{\circ} \mathrm{C}$ for $35 \mathrm{sec}, 58^{\circ} \mathrm{C}$ for $35 \mathrm{sec}\left(-1^{\circ} \mathrm{C} /\right.$ cycle $), 72^{\circ} \mathrm{C}$ for 100 sec. The touchdown cycles were followed by 30 cycles of $94^{\circ} \mathrm{C}$ for $35 \mathrm{sec}, 50^{\circ} \mathrm{C}$ for $35 \mathrm{sec}, 72^{\circ} \mathrm{C}$ for $100 \mathrm{sec}$, with a final extension of $72^{\circ} \mathrm{C}$ for $7 \mathrm{~min}$. Reactions were conducted using either a Gene Amp 9700 (Applied Biosystems, Carlsbad, CA) or a PTC-200 (MJ Research, Waltham, MA) thermal cycler.

An aliquot $(2 \mu \mathrm{l})$ from a 1:40 dilution of the first PCR product was used as input for a second round of PCR, carried out in $10 \mu \mathrm{l}$ final volume with $0.2 \mathrm{mM}$ each dNTP, 0.25 U ExTaq HS DNA Polymerase (TaKaRa Bio Inc, Shiga, Japan) with IRDye-labeled primers (MWG Biotech, Huntsville, AL), designed to specifically amplify one gene copy. Labeled and unlabeled primers $(100 \mu \mathrm{M}$ stocks) were mixed into a cocktail in a ratio of 3 parts IRD-700-labeled 5' primer: 2 parts unlabeled 5' primer: 4 parts IRD-800-labeled 3' primer: 1 part unlabeled 3' primer. Concentrations of primer cocktail, PCR buffer, and $\mathrm{MgCl}_{2}$ were optimized for each individual gene. Touchdown PCR was conducted in a PTC-200 thermal cycler (MJ Research, Waltham, MA) as follows: denaturation at $95^{\circ} \mathrm{C}$ for $2 \mathrm{~min}$ followed by 6 cycles of $94^{\circ} \mathrm{C}$ for $30 \mathrm{sec}, 58^{\circ} \mathrm{C}$ for $30 \mathrm{sec}\left(-1^{\circ} \mathrm{C} /\right.$ cycle $)$, temperature ramp $+0.5^{\circ} \mathrm{C} / \mathrm{sec}$ to $72^{\circ} \mathrm{C}$ for $80 \mathrm{sec}$; then 45 cycles of $94^{\circ} \mathrm{C}$ for $30 \mathrm{sec}, 52^{\circ} \mathrm{C}$ for $30 \mathrm{sec}$ with a temperature ramp $+0.5^{\circ} \mathrm{C} / \mathrm{sec}$ to $72^{\circ} \mathrm{C}$ for $80 \mathrm{sec}$. This was followed by a final extension at $72^{\circ} \mathrm{C}$ for $7 \mathrm{~min}$. PCR was immediately followed by the heteroduplex formation step: denaturation at $99^{\circ} \mathrm{C}$ for $10 \mathrm{~min}, 70$ cycles of reannealing at $70^{\circ} \mathrm{C}$ for $20 \mathrm{sec}$, decreasing $0.3^{\circ} \mathrm{C} / \mathrm{cycle}$, with a final hold at $4^{\circ} \mathrm{C}$.

\section{Preparation of Celery Juice Extract (CEL1 Nuclease)}

Celery juice extract (CJE), containing CEL1 nuclease, was prepared following the purification protocol from Till et al. [46] with minor modifications. The endonuclease activity and the concentration were tested using a plasmid nicking assay as follows: $200 \mathrm{ng}$ of circular plasmid were incubated with $10 \mu \mathrm{l}$ of CJE dilution in $1 \times$ CELI Buffer (10 mM MgSO $4,10 \mathrm{mM}$ HEPES, $10 \mathrm{mM}$ $\mathrm{KCl}, 0.02 \%$ Triton $\mathrm{X}-100,0.002 \%$ bovine serum albu$\min )$ in $20 \mu \mathrm{l}$ final volume. After incubation at $45^{\circ} \mathrm{C}$ for $15 \mathrm{~min}$, the sample was placed on ice and $10 \mu \mathrm{l}$ of 0.15 $M$ EDTA was added to stop the reaction. The digestion products were analyzed on $1 \%$ agarose gel. The activity of the CJE was compared with that of Surveyor Nuclease (Transgenomic, Omaha, NE) on a known mutant, detected previously by EcoTILLING $[38,47]$.

\section{Mutation Screening}

After PCR amplification, samples $(5 \mu$ from the second PCR) were digested in $1 \times$ CEL1 Buffer with 0.03-0.06 $\mu \mathrm{l} \mathrm{CJE}$ in $10 \mu \mathrm{l}$ total volume, incubated for $15 \mathrm{~min}$ at $45^{\circ} \mathrm{C}$ as described by Till et al. [46]. To stop the reaction $5 \mu \mathrm{l}$ of $0.15 \mathrm{M}$ EDTA was added per sample, while keeping the samples on ice. The samples were cleaned using Sephadex G-50 (Sigma, Saint Louis, MO), uniformly loaded in 96-well MultiScreen-HV filter plates using a 45- $\mu$ l MultiScreen Column Loader (Millipore, Billerica, MA) following the manufacturer's instructions. The samples were collected in a catch plate, transferred to a 96-well PCR plate, and dried in an ISS110 Speed Vac centrifugal evaporator (Thermo Savant, Milford, MA). The dried samples were resuspended in $8 \mu \mathrm{l}$ of formamide loading buffer ( $37 \%$ formamide, $3.75 \mathrm{mM}$ EDTA pH 8, 0.0075\% bromophenol blue), and then heated to $80^{\circ} \mathrm{C}$ for $7 \mathrm{~min}$, and then to $92^{\circ} \mathrm{C}$ for $2 \mathrm{~min}$ [30]. Samples could then be stored in the dark at $4^{\circ} \mathrm{C}$ for several days until analysis. Samples $(0.8 \mu \mathrm{l})$ were loaded on $6.5 \%$ polyacrylamide gel in $1 \times \mathrm{TBE}$ and electrophoresed at $1500 \mathrm{~V}, 40 \mathrm{~mA}, 30 \mathrm{~W}$, at $45^{\circ} \mathrm{C}$ on a LiCor 4300 DNA Analyzer (Li-Cor Biosciences, Lincoln, $\mathrm{NE}$ ). Images were visually analyzed for the presence of cleavage products using Adobe Photoshop (Adobe Systems, Inc, San Jose, CA) and GelBuddy [48]. Putative mutations were identified by fragments appearing in both the 700 and 800 channels, with sizes adding up to that of the full-length PCR product. Because the DNA was pooled four-fold for initial screening, each of the four individuals was then screened against wild type (Tifrunner) to identify the mutant. 
Mutations were confirmed by cloning PCR-amplified genes or gene fragments into the pCR4-TOPO cloning vector using the TOPO-TA Cloning Kit for Sequencing (Invitrogen, Carlsbad, CA) according to the manufacturer's instructions, followed by sequencing with M13 forward and reverse primers. Mutation frequency was estimated as the total number of confirmed mutations divided by the total number of base pairs screened [(amplicon size $-200 \mathrm{bp}) \times$ individuals screened)]. For each amplicon, $200 \mathrm{bp}$ is subtracted to adjust for the 100-bp regions at the top and bottom of TILLING gel images that are difficult to analyze [5].

\section{SDS-PAGE, Western Blots, and IgE-Binding Analysis}

Seed protein extraction was carried out as described by Koppelman et al. [3]. Protein quantification was performed using the Bio-Rad Protein Assay kit (Bio-Rad, Hercules, CA) and bovine serum albumin (BSA) as the standard. Ten micrograms of total protein were loaded per lane and separated in 12\% SDS-PAGE gels. The proteins were then electroblotted at $30 \mathrm{~V}$ overnight to PVDF membranes, $0.2 \mu \mathrm{m}$ (Bio-Rad). The membranes were blocked with $5 \%$ non-fat dry milk in PBS-T (137 $\mathrm{mM} \mathrm{NaCl}, 2.7 \mathrm{mM} \mathrm{KCl}, 1.4 \mathrm{mM} \mathrm{KH}{ }_{2} \mathrm{PO}_{4}, 4.3 \mathrm{mM}$ $\mathrm{Na}_{2} \mathrm{HPO}_{4}, 0.1 \%$ Tween-20) at room temperature for $1 \mathrm{~h}$ with gentle agitation. For Western blot analysis, after blocking the membrane was probed with chicken antiAra h 2 or anti-Ara h 1 (1:8,000 dilution) primary antibodies for $1 \mathrm{~h}$ followed by secondary anti-chicken antibody-horseradish peroxidase (HRP; 1:100,000; Sigma, Saint Louis, MO) in PBS-T with $2 \%$ non-fat dry milk for $1 \mathrm{~h}$. For IgE binding analysis, sera were obtained from four individuals (HW, DAM, CM, and NF) documented as allergic to peanuts with either a positive food challenge or a convincing history of peanut allergy. Sera from allergic individuals were collected at the University of Arkansas for Medical Sciences, Little Rock, AR, approved and in accordance with the rules and regulations of the institutional review board. Blots incubated with a 1:20 dilution of the four sera were allowed to hybridize overnight at $4^{\circ} \mathrm{C}$. All membranes were washed three times with PBS-T for 5 min after each antibody incubation. ECL Plus detection reagents (Amersham Biosciences) were used for chemifluorescent detection, followed by scanning on a Storm 840 imaging system (Amersham Biosciences). For IgE binding analysis, relative quantification of Ara h 2.01 protein was performed by densitometry with Quantity One software (Bio-Rad) and all samples were normalized to the amount of Ara h $2.01 / 10 \mu \mathrm{g}$ of total protein in wild-type. Further IgE immunoblot analyses were performed using $100 \mathrm{ng}$ of Ara h 2.01-normalized total protein.

\section{2-D PAGE and DIGE}

Suspected homozygous knockout mutants of Ara h 2.02 and Ara h 1.02 were subjected to two-dimensional protein analyses using difference gel electrophoresis (2-D DIGE) essentially according to Chu et al. [4]. Labeled protein samples for analysis of 17-19 kD Ara h 2 (wildtype - Cy3; mutant - Cy2) were resolved using $\mathrm{p} I$ 3-10 immobilized $\mathrm{pH}$ gradient (IPG) strips. For analysis of $\sim 65 \mathrm{kD}$ Ara h 1, $50 \mu \mathrm{g}$ each of Cy3-labeled wild-type, Cy5-labeled mutant, and Cy2-labeled mixture of wildtype and mutant protein extracts were mixed and focused in a 24-cm pH 5.3-6.5 IPG strip at 10,000 V for $121 \mathrm{kVhr}$ before running the second dimension in a 10\% Tris-glycine SDS-PAGE gel. Labeled spots were detected with a Typhoon 9400 Variable Mode Imager (GE Healthcare) and digital image analysis was conducted with SameSpot Progenesis (Nonlinear Dynamics).

\section{Additional material}

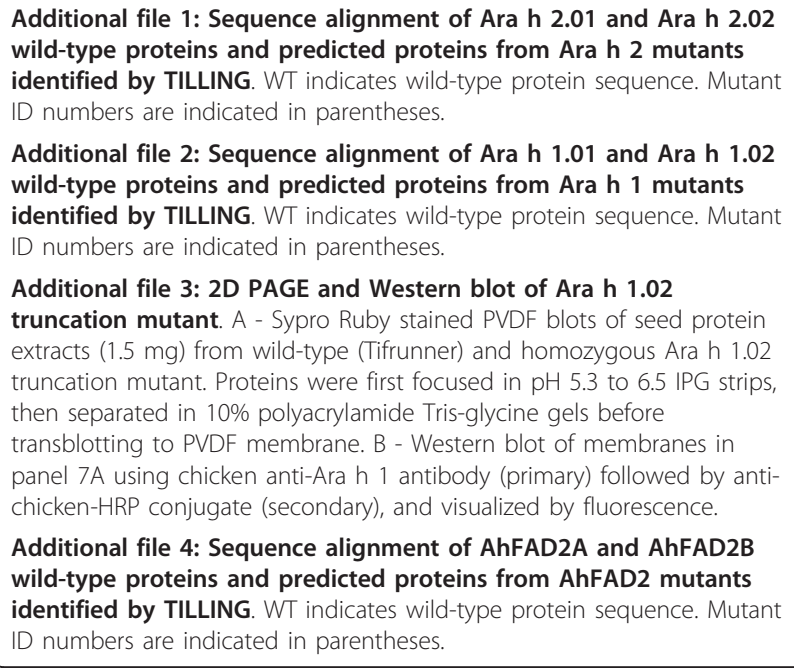

Additional file 4: Sequence alignment of AhFAD2A and AhFAD2B wild-type proteins and predicted proteins from AhFAD2 mutants identified by TILLING. WT indicates wild-type protein sequence. Mutant ID numbers are indicated in parentheses.

\section{Acknowledgements}

This work was supported by the Consortium for Plant Biotechnology Research, The Georgia Peanut Commission, the Peanut Foundation, the National Peanut Board and USDA Specific Cooperative Agreement 58-64356-050. We thank Evelyn Perry Morgan for technical assistance and Ye Chu for helpful discussion.

\section{Author details}

${ }^{1}$ Department of Horticulture/NESPAL, University of Georgia-Tifton Campus, Tifton, GA 31793, USA. ²USDA-ARS Crop Genetics and Breeding Research Unit, Tifton, GA 31793, USA. ${ }^{3}$ Interdisciplinary Center for Biotechnology Research, University of Florida, Gainesville, FL 32611, USA. ${ }^{4}$ USDA-ARS Southern Regional Research Center, New Orleans, LA 70124, USA.

\section{Authors' contributions}

JEK performed Southern blot analysis for Ara h 1, screened and identified mutants, and drafted the manuscript. MLR developed the TILLING protocols used in this study, prepared celery juice extract, and screened and identified 
mutants. $A B$ assisted in screening and identifying mutants. POA was the lead investigator, generated the mutagenized populations, and also drafted the manuscript. YZ, MC, and SC performed 2D PAGE and DIGE on the protein extracts from knockout mutants. SM performed lgE binding analysis on mutant Ara h 2.01 proteins. CCH assisted in generating, advancing, and maintaining the mutagenized populations. All authors have read and approved the manuscript.

\section{Authors' information}

Current addresses:

JEK - USDA-ARS Crop Genetics and Breeding Research Unit, Tifton, GA 31793, USA

MLR - NIDERA S.A., Departamento de Biotecnologia, Venado Tuerto, Santa Fe CP2600, Argentina

$A B$ - Bench Biotechnology, Vapi, Gujarat, India

Received: 10 January 2011 Accepted: 12 May 2011

Published: 12 May 2011

\section{References}

1. Palmer $\mathrm{K}$, Burks W: Current developments in peanut allergy. Curr Opin Allergy Clin Immunol 2006, 6:202-206.

2. International Union of Immunological Societies: Allergen nomenclature. [http://www.allergen.org/index.php].

3. Koppelman SJ, Vlooswijk RAA, Knippels LMJ, Hessing M, Knol EF, van Reijsen FC, Bruijnzeel-Koomen CAFM: Quantification of major peanut allergens Ara $\mathrm{h} 1$ and Ara $\mathrm{h} 2$ in the peanut varieties Runner, Spanish, Virginia, and Valencia, bred in different parts of the world. Allergy 2001, 56:132-137.

4. Chu Y, Faustinelli P, Ramos ML, Hajduch M, Stevenson S, Thelen JJ, Maleki S, Cheng H, Ozias-Akins P: Reduction of IgE binding and nonpromotion of Aspergillus flavus fungal growth by simultaneously silencing Ara $\mathrm{h} 2$ and Ara h 6 in peanut. J Agric Food Chem 2008, 56:11225-11233.

5. Greene EA, Codomo CA, Taylor NE, Henikoff JG, Till BJ, Reynolds SH, Enns LC, Burtner C, Johnson JE, Odden AR, Comai L, Henikoff S: Spectrum of chemically induced mutations from a large-scale reverse-genetic screen in Arabidopsis. Genetics 2003, 164:731-740.

6. Till BJ, Cooper J, Tai TH, Colowit P, Greene EA, Henikoff S, Comai L: Discovery of chemically induced mutations in rice by TILLING. BMC Plant Biol 2007, 7:19

7. Till BJ, Reynolds SH, Weil C, Springer N, Burtner C, Young K, Bowers E, Codomo CA, Enns LC, Odden AR, Greene EA, Comai L, Henikoff S: Discovery of induced point mutations in maize genes by TILLING. BMC Plant Biol 2004, 4:12.

8. Cooper JL, Till BJ, Laport RG, Darlow MC, Kleffner JM, Jamai A, El-Mellouki T, Liu S, Ritchie R, Nielsen N, Bilyeu KD, Meksem K, Comai L, Henikoff S: TILLING to detect induced mutations in soybean. BMC Plant Biol 2008, 8:9.

9. Ramos ML, Fleming G, Chu Y, Akiyama Y, Gallo M, Ozias-Akins P: Chromosomal and phylogenetic context for conglutin genes in Arachis based on genomic sequence. Mol Genet Genomics 2006, 275:578-592.

10. St. Angelo AJ, Ory RL: Investigations of causes and prevention of fatty acid peroxidation in peanut butter. J Am Peanut Res Educ Soc 1973, 5:128-133.

11. Moore KM, Knauft DA: The inheritance of high-oleic acid in peanut. $J$ Hered 1989, 80:252-253

12. Jung $S$, Swift D, Sengoku E, Patel M, Teulé F, Powell G, Moore $K$, Abbott A: The high oleate trait in the cultivated peanut (Arachis hypogaea L.) I. Isolation and characterization of two genes encoding microsomal oleoyl-PC desaturases. Mol Gen Genet 2000, 263:796-805.

13. Jung $S$, Powell $G$, Moore $K$, Abbott A: The high oleate trait in the cultivated peanut (Arachis hypogaea L.) II. Molecular basis and genetics of the trait. Mol Gen Genet 2000, 263:806-811.

14. Stanley JS, King N, Burks AW, Huang SK, Sampson H, Cockrell G, West CM, Bannon GA: Identification and mutational analysis of the immunodominant $\mathrm{lgE}$ binding epitopes of the major peanut allergen Ara h 2. Arch Biochem Biophys 1997, 342:244-253.

15. Schein $\mathrm{CH}$, Ivanciuc $\mathrm{O}$, Braun W: Common physical-chemical properties correlate with similar structure of the IgE epitopes of peanut allergens. J Agric Food Chem 2005, 53:8752-8759.
16. Ozias-Akins $P$, Ramos ML, Chu Y: Hypoallergenic foods beyond infant formulas. In Food Allergy: Comprehension, Treatment, and Prevention. Edited by: Maleki S, Burks AW, Helm RM. Herndon, VA: ASM Press; 2006:287-308.

17. Viquez OM, Konan KN, Dodo HW: Structure and organization of the genomic clone of a major peanut allergen gene, Ara h 1 . Mol Immunol 2003, 40:565-571.

18. Li H-G, Wang L, Zhang Y-S, Lin X-D, Liao B, Yan Y-S, Huang S-Z: Cloning and sequencing of the gene $A h y-\beta$ encoding a subunit of peanut conarachin. Plant Sci 2005, 168:1387-1392.

19. Chassaigne H, Trégoat V, Nørgaard JV, Maleki SJ, van Hengel AJ: Resolution and identification of major peanut allergens using a combination of fluorescence two-dimensional differential gel electrophoresis, Western blotting and Q-TOF mass spectrometry. J Proteomics 2009, 72:511-526.

20. López Y, Nadaf HL, Smith OD, Connell JP, Reddy AS, Fritz AK: Isolation and characterization of the $\Delta^{12}$-fatty acid desaturase in peanut (Arachis hypogaea $\mathrm{L}$.) and search for polymorphisms for the high oleate trait in Spanish market-type lines. Theor Appl Genet 2000, 101:1131-1138.

21. Patel M, Jung S, Moore K, Powell G, Ainsworth C, Abbott A: High-oleate peanut mutants result from a MITE insertion into the FAD2 gene. Theor Appl Genet 2004, 108:1492-1502.

22. Branch WD: Registration of 'Georgia Green' peanut. Crop Sci 1996, 36:806.

23. Holbrook CC, Culbreath AK: Registration of 'Tifrunner' peanut. J Plant Registrations 2007, 1:124.

24. Li JX, Shefcheck K, Callahan J, Fenselau C: Primary sequence and siteselective hydroxylation of prolines in isoforms of a major peanut allergen protein Ara h 2. Protein Sci 2010, 19:174-182.

25. Shin DS, Compadre CM, Maleki SJ, Kopper RA, Sampson H, Huang SK, Burks AW, Bannon GA: Biochemical and structural analysis of the IgE binding sites on Ara $\mathrm{h} \mathrm{1}$, an abundant and highly allergenic peanut protein. J Biol Chem 1998, 273:13753-13759.

26. Burks AW, Williams LW, Helm RM, Connaughton C, Cockrell G, Obrien T: Identification of a major peanut allergen, Ara- $\mathrm{H}-\mathrm{I}$, in patients with atopic-dermatitis and positive peanut challenges. J Allergy Clin Immunol 1991, 88:172-179.

27. Chu Y, Holbrook CC, Ozias-Akins P: Two alleles of ahFAD2B control the high oleic acid trait in cultivated peanut. Crop Sci 2009, 49:2029-2036

28. Xin Z, Wang ML, Barkley NA, Burow G, Franks C, Pederson G, Burke J: Applying genotyping (TILLING) and phenotyping analyses to elucidate gene function in a chemically induced sorghum mutant population. BMC Plant Biol 2008, 8:103.

29. Perry JA, Wang TL, Welham TJ, Gardner S, Pike JM, Yoshida S, Parniske M: A TILLING reverse genetics tool and a web-accessible collection of mutants of the legume Lotus japonicus. Plant Physiol 2003, 131:866-871.

30. Slade AJ, Fuerstenberg SI, Loeffler D, Steine MN, Facciotti D: A reverse genetic, nontransgenic approach to wheat crop improvement by TILLING. Nat Biotechnol 2005, 23:75-81.

31. Triques $\mathrm{K}$, Sturbois B, Gallais $\mathrm{S}$, Dalmais $\mathrm{M}$, Chauvin $\mathrm{S}$, Clepet $\mathrm{C}$, Aubourg $\mathrm{S}$, Rameau C, Caboche M, Bendahmane A: Characterization of Arabidopsis thaliana mismatch specific endonucleases: application to mutation discovery by TILLING in pea. Plant J 2007, 51:1116-1125.

32. Dalmais M, Schmidt J, Le Signor C, Moussy F, Burstin J, Savois V, Aubert G, Brunaud V, de Oliveira Y, Guichard C, Thompson R, Bendahmane A: UTILLdb, a Pisum sativum in silico forward and reverse genetics tool. Genome Biol 2008, 9:R43.

33. Lababidi S, Mejhede N, Rasmussen SK, Backes G, Al-Said W, Baum M, Jahoor A: Identification of barley mutants in the cultivar 'Lux' at the Dhn loci through TILLING. Plant Breed 2009, 128:332-336.

34. Caldwell DG, McCallum N, Shaw P, Muehlbauer GJ, Marshall DF, Waugh R: A structured mutant population for forward and reverse genetics in barley (Hordeum vulgare L.). Plant J 2004, 40:143-150.

35. Wu JL, Wu CJ, Lei CL, Baraoidan M, Bordeos A, Madamba MRS, RamosPamplona M, Mauleon R, Portugal A, Ulat VJ, Bruskiewich R, Wang GL, Leach J, Khush G, Leung H: Chemical- and irradiation-induced mutants of indica rice IR64 for forward and reverse genetics. Plant Mol Biol 2005, 59:85-97.

36. Talame V, Bovina R, Sanguineti MC, Tuberosa R, Lundqvist U, Salvi S: TILLMore, a resource for the discovery of chemically induced mutants in barley. Plant Biotechnol J 2008, 6:477-485.

37. Moore KM: High oleic acid peanut. U.S. Patent no. 59455781999.

38. Ramos ML, Huntley JJ, Maleki SJ, Ozias-Akins P: Identification and characterization of a hypoallergenic ortholog of Ara $\mathrm{h}$ 2.01. Plant Mol Biol 2009, 69:325-335. 
39. De Jong EC, van Zijverden M, Spanhaak S, Koppelman SJ, Pellegrom H, Penninks AH: Identification and partial characterization of multiple major allergens in peanut proteins. Clin Exp Allergy 1998, 28:743-751.

40. Wichers HJ, de Beijer T, Savelkoul HFJ, van Amerongen A: The major peanut allergen Ara $\mathrm{h} 1$ and its cleaved-off $\mathrm{N}$-terminal peptide; possible implications for peanut allergen detection. J Agric Food Chem 2004, 52:4903-4907.

41. Burks AW, Shin D, Cockrell G, Stanley JS, Helm RM, Bannon GA: Mapping and mutational analysis of the lgE-binding epitopes on Ara $\mathrm{h} \mathrm{1,} \mathrm{a}$ legume vicilin protein and a major allergen in peanut hypersensitivity. Eur J Biochem 1997, 245:334-339.

42. Chu Y, Ramos L, Holbrook CC, Ozias-Akins P: Frequency of a loss-offunction mutation in oleoyl-PC-desaturase (ahFAD2A) in the mini-core of the U.S. peanut germplasm collection. Crop Sci 2007, 47:2372-2378.

43. Bruner $A C$, Jung $S$, Abbott $A G$, Powell $G L$ : The naturally occurring high oleate oil character in some peanut varieties results from reduced oleoyl-PC desaturase activity from mutation of aspartate 150 to asparagine. Crop Sci 2001, 41:522-526.

44. Sharma KK, Lavanya M, Anjaiah V: A method for the isolation and purification of peanut genomic DNA suitable for analytical applications. Plant Mol Biol Rep 2000, 18:393a-393h.

45. Sambrook J, Russell DW: Molecular Cloning: A Laboratory Manual. 3 edition. Cold Spring Harbor, NY: Cold Spring Harbor Laboratory Press; 2001.

46. Till BJ, Zerr T, Comai L, Henikoff S: A protocol for TILLING and EcoTILLING in plants and animals. Nat Protocols 2006, 1:2465-2477.

47. Comai L, Young K, Till BJ, Reynolds SH, Greene FA, Codomo CA, Enns LC, Johnson JE, Burtner C, Odden AR, Henikoff S: Efficient discovery of DNA polymorphisms in natural populations by EcoTILLING. Plant J 2004, 37:778-786.

48. Zerr T, Henikoff S: Automated band mapping in electrophoretic gel images using background information. Nucleic Acids Res 2005, 33:2806-2812

doi:10.1186/1471-2229-11-81

Cite this article as: Knoll et al:: TILLING for allergen reduction and improvement of quality traits in peanut (Arachis hypogaea L.). BMC Plant Biology 2011 11:81.

\section{Submit your next manuscript to BioMed Central and take full advantage of:}

- Convenient online submission

- Thorough peer review

- No space constraints or color figure charges

- Immediate publication on acceptance

- Inclusion in PubMed, CAS, Scopus and Google Scholar

- Research which is freely available for redistribution

Submit your manuscript at www.biomedcentral.com/submit 